\title{
Multiloci analyses suggest synonymy among Rhomboplites, Ocyurus and Lutjanus and reveal the phylogenetic position of Lutjanus alexandrei (Lutjanidae: Perciformes)
}

\author{
Ivana Veneza ${ }^{1}$, Raimundo da Silva ${ }^{1}$, Danillo da Silva ${ }^{1}$, Grazielle Gomes $^{1,2}$, \\ Iracilda Sampaio ${ }^{2}$ and Horacio Schneider ${ }^{2}$
}

Lutjanidae comprises 21 genera and 135 species widespread throughout Atlantic, Indian and Pacific oceans. Nonetheless, the phylogenetic relationships of Lutjaninae remain uncertain. Furthermore, phylogenetic hypotheses for Lutjanus alexandrei, an endemic species from northeastern Brazilian coast, in Lutjanidae are absent so far. Therefore, we carried out multiloci analyses, combining both mitochondrial and nuclear DNA sequences in Lutjaninae species from Western Atlantic focusing on the controversial relationships among Lutjanus, Rhomboplites, and Ocyurus. Besides, we determined the phylogenetic position and dated the origin of $L$. alexandrei. The phylogenetics trees based on the $4.4 \mathrm{~kb}$ for 11 species corroborated the synonym among Lutjanus and the putative monotypic genera. For the dating of $L$. alexandrei, another nucleotide dataset (3.0 $\mathrm{kb} ; 40$ species) validated the genetic identity of this species that diverged from the sister taxon $L$. apodus between $2.5-6.5$ Mya, probably as a result of the barrier caused by the muddy outflow from Orinoco and Amazon rivers along the coastal zone. This report is the most robust multiloci analysis to confirm the synonymy of the three genera of Lutjaninae from Western Atlantic and the first reliable inference about the phylogenetic relationships and origin of L. alexandrei.

Keywords: DNA, Lutjaninae, Phylogeny Molecular, Systematics, Taxonomy.

A Família Lutjanidae compreende 21 gêneros e 135 espécies, distribuídas ao longo dos oceanos Atlântico, Índico e Pacífico. As relações filogenéticas dos Lutjaninae são incertas. Além disso, a espécie Lutjanus alexandrei, endêmica da costa nordeste do Brasil, não foi inclusa em nenhuma hipótese filogenética até o presente. Assim, realizamos uma análise integrando DNA mitocondrial e nuclear para espécies de Lutjaninae do Atlântico Ocidental, direcionada para a controversa relação entre Lutjanus, Rhomboplites e Ocyurus. Além disso, alocamos filogeneticamente L. alexandrei e datamos sua origem. As árvores filogenéticas baseadas em $4.4 \mathrm{~kb}$ de 11 espécies corroboraram a sinonímia entre os monotípicos e Lutjanus. Para a datação de L. alexandrei, outro banco de nuclueotídeos foi analisado (3.0 kb; 40 espécies), validando geneticamente a espécie e a colocando como irmã de L. apodus, da qual se separou entre 2.5 - 6.5 Mya, o que provavelmente foi provocado pela faixa enlameada na região costeira, influenciada pelas descargas dos rios Amazonas e Orinoco, que funciona como barreira. Este trabalho representa a mais robusta análise multiloci direcionada para a sinonimização dos três gêneros de Lutjaninae e a primeira hipótese filogenética a propor um posicionamento e origem para L. alexandrei.

Palavras-chave: DNA, Filogenia Molecular, Lutjaninae, Sistemática, Taxonomia.

\section{Introduction}

Lutjanidae is a fish family mainly composed of marine demersal species that can be found up to $550 \mathrm{~m}$ deep, even though each species seems to present specific depth preferences. In general, the lutjanids (or snappers) inhabit coastal tropical and subtropical waters in association with rocky bottom and coral reefs, even though some species depend on estuaries during early life cycle (Cervigón, 1993; Nelson et al., 2016). The snappers show remarkable phenotypic variation and medium- to large-sized bodies (up to $1 \mathrm{~m}$ in total length), representing important fishery resources along their range (Cervigón, 1993; Nanami, Yamada, 2008; MPA, 2009, 2010, 2011).

\footnotetext{
${ }^{1}$ Universidade Federal do Pará, Instituto de Estudos Costeiros, Laboratório de Genética Aplicada, Alameda Leandro Ribeiro, S/N, Aldeia, 68600-000 Bragança, PA, Brazil. (IV) ivana_veneza@hotmail.com, ○https://orcid.org/0000-0002-3528-1290 (corresponding author); (RS) yelrad37@yahoo.com.br, Dhttps://orcid.org/0000-0002-3003-7272; (DS) danilloufpa@gmail.com, Dhttps://orcid.org/0000-00026248-4253; (GG) graziellefeg@gmail.com, Dhttps://orcid.org/0000-0001-8898-0311

${ }^{2}$ Universidade Federal do Pará, Instituto de Estudos Costeiros, Laboratório de Genética e Biologia Molecular, Alameda Leandro Ribeiro, S/N, Aldeia, 68600-000 Bragança, PA, Brazil. (IS) ira@ufpa.br, Dhttps://orcid.org/0000-0002-2137-4656; (HS) horacio@ufpa.br, Dhttps:// orcid.org/0000-0002-5987-6395. In memoriam
} 
This family has a close phylogenetic relationship with Caesionidae (fusiliers), with much evidence that it is in fact a single family, with Caesionidae being incorporated as a subfamily of Lutjanidae (Johnson, 1993; Miller, Cribb, 2007; Betancur-R et al., 2013; Frédérich, Santini, 2017). Thus, composed of nearly 21 genera and 135 species, the family Lutjanidae is organized into five subfamilies: Etelinae, Apsilinae, Paradicichthyinae, Lutjaninae, and Caesioninae (Allen, 1985; Cervigón, 1993; Betancur-R et al., 2013; Nelson et al., 2016; Betancur-R et al., 2013; Frédérich, Santini, 2017; Eschmeyer, Fong, 2018). These fishes are widespread throughout Atlantic, Indian and Pacific oceans, being the latter characterized by the highest diversity of lutjanids (Allen, 1985; Hastings et al., 2014).

The subfamily Lutjaninae comprises six genera Pinjalo Bleeker, 1873; Macolor Bleeker, 1860; Hoplopagrus Gill, 1861; Ocyurus Gill, 1862; Rhomboplites Gill, 1862, and Lutjanus Bloch, 1790 with about 78 species. Fourteen species are reported in Western Atlantic (WA), being 12 species of Lutjanus while the remaining ones are included in monotypic genera endemic to WA: Rhomboplites aurorubens (Cuvier, 1829) and Ocyurus chrysurus (Bloch, 1791) (Allen, 1985; Cervigón, 1993; Nelson et al., 2016).

Within Lutjanus, the most species-rich genus of Lutjanidae, the Brazilian snapper (L. alexandrei Moura, Lindeman, 2007) stands out as an endemic species of the Brazilian coast. In the description report of this taxon, the authors highlighted that L. alexandrei is a common species from estuarine and reef environments that has been traditionally misidentified as L. griseus (Linnaeus, 1758) or L. apodus (Walbaum, 1792), suggesting that both taxa are not found in Brazil (Moura, Lindeman, 2007). Nonetheless, molecular studies that attempted to validate the phenotypic description of $L$. alexandrei or to infer the phylogenetic position of this taxon are absent so far.

Indeed, the available phylogenetic hypotheses of snappers, particularly in relation to Lutjaninae species from WA, are conflicting. In this context, a long debate refers to the validation of Rhomboplites and Ocyurus as monotypic genera. Both genera were defined according to morphological traits (Evermann, Marsh, 1900; Vergara, 1980), but several studies have shown their close relationship with Lutjanus representatives. While protein analyses reinforced the separation of Rhomboplites as a distinct genus, they provided no evidence for placing $O$. chrysurus apart from Lutjanus (Chow, Walsh, 1992).

Furthermore, some molecular phylogenies support the inclusion of $O$. chrysurus within Lutjanus and cast doubt on the taxonomic status of Rhomboplites (Sarver et al., 1996). The taxonomic classification of these genera has also called into question based on cytogenetic data since chromosomal differences were observed between Rhomboplites and Lutjanus but not between the latter and Ocyurus (Nirchio et al., 2009).

Based on mitochondrial DNA (mtDNA), Gold et al. (2011) inferred the evolutionary relationships of 20 species of Lutjaninae (12 taxa from WA, one species from Pacific Ocean and seven from Indo-Pacific). According to their results, the authors recommended that the monotypic genera should be included within Lutjanus.

Later, Gold et al. (2015) proposed a phylogenetic hypothesis for snappers from Eastern Pacific that also included species from WA, Indo-Pacific, and Western Indian oceans. Again, the molecular data (mtDNA sequences) clustered together Rhomboplites, Ocyurus, and Lutjanus.

Even though there are several pieces of evidence for the synonymy among Ocyurus, Rhomboplites and Lutjanus, no conclusive study has already been reported, possibly because the available morphological analyses were based on limited sampling with a few species. Moreover, there is only one phylogenetic study using a single nuclear gene in Lutjanidae (Frédérich, Santini, 2017).

Therefore, the present study provided a thorough phylogenetic inference of Lutjaninae from WA, based on the most extensive molecular data so far, comprising seven loci from mitochondrial and nuclear genome regions. We carried out an integrative analysis focusing on the controversial relationships among Lutjanus, Rhomboplites and Ocyurus, aiming to reinforce the synonimization. Furthermore, we wanted to propose the phylogenetic position and origin period of L. alexandrei.

\section{Material and Methods}

Sampling. This study comprised two sample sets. The first one was used for the phylogenetic inferences of Lutjaninae from WA, which included 11 species, being nine of Lutjanus (L. purpureus (Poey, 1866); L. campechanus (Poey, 1860); L. vivanus (Cuvier, 1828); L. buccanella (Cuvier, 1828); L. analis (Cuvier, 1828); L. synagris (Linnaeus, 1758); L. jocu (Bloch, Schneider, 1801); L. alexandrei; L. cyanopterus (Cuvier, 1828) and the monotypic taxa $R$. aurorubens and $O$. chrysurus). In addition, Etelis oculatus (Valenciennes, 1828) (Etelinae) and Conodon nobilis (Linnaeus, 1758) (Haemulidae) were included, totaling 24 specimens (Tab. 1).

The second sample set was more diversified and used to determine the diversification period of $L$. alexandrei, thus comprising Lutjaninae species from other regions as well as other subfamilies, totaling 53 specimens. In total, 40 species of snappers+fusiliers were analyzed, being 27 of Lutjaninae with five out of the six genera recognized for this subfamily (Lutjanus, Macolor, Hoplopagrus, Rhomboplites, and Ocyurus); five Etelinae species from four of the five valid genera (Etelis, Pristipomoides Bleeker, 1852; Aphareus Valenciennes, 1830, and Aprion Valenciennes, 1830); the two monotypic genera of Paradicichthyinae (Symphorus Günther, 1872 and Symphorichthys Munro, 1967); and five Caesioninae species from two of the four valid genera (Caesio Lacepède, 1801 and Pterocaesio Bleeker, 1876) (Tab. 1). 
Tab. 1. Markers and their evolutionary rates included in the present study, with respective Genbank access codes of sequence data. The species in bold represent specimens samples in the present study selected for the phylogenetic analyses (BI and ML) in Western Atlantic species of Lutjaninae, based on all markers. The total set of species was used to infer the evolutionary relationships and the origin of Lutjanus alexandrei within Lutjanidae, based on the highlighted markers. * Haemulidae representatives used as outgroups used in phylogenetic trees.

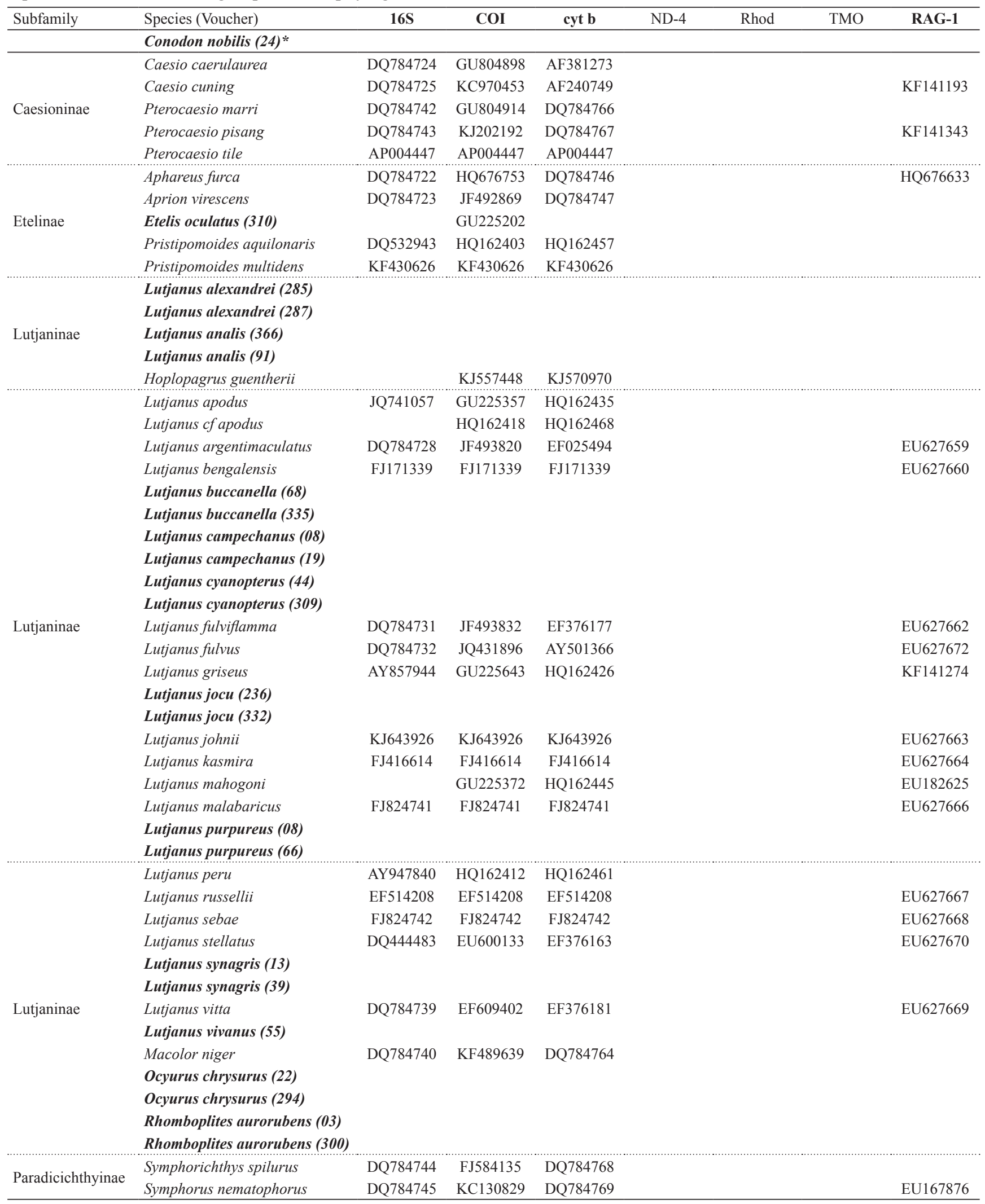


In both sets, Conodon nobilis was used as outgroup since Haemulidae has been regarded as the sister group of Lutjanidae (Betancur-R et al., 2013; Near et al., 2013).

A great portion of the sampling derived from collection expeditions from the present study, while the remaining samples included sequences available in GenBank. Muscle tissues were collected from $C$. nobilis and all species of snappers from WA, except for L. apodus; L. griseus; $L$. mahogoni (Cuvier, 1828); Pristipomoides and Apsilus. These samples are originated from local fish markets, trawl net expeditions and fishing landing ports along the American coast, as detailed in Tab. 1. The fish from which samples were taken, were not collected exclusively for this study. They were captured with fishermen support who available only the samples and later destined the whole fish for markets, without some structures like gut, stomach. In this way, not possible the deposit of individuals in a museum.

The samples were stored in microtubes, preserved in $90 \%$ ethanol and transported to the laboratory and kept at $-20^{\circ} \mathrm{C}$ up to their utilization.

Isolation, amplification, and DNA sequencing. Total genomic DNA was isolated using commercial kits (Wizard Genomic ${ }^{\circledR}$, PROMEGA), according to the manufacturer's instructions. The extracted DNA was visualized after electrophoresis in $1 \%$ agarose gel stained with Gel $\operatorname{Red}^{\mathrm{TM}}$ (BIOTIUM) under ultraviolet light. The selected genome regions were amplified via PCR, comprising four mitochondrial genes (16S rRNA - 16S, cytochrome c oxidade subunit 1 - COI, cytochrome b - cyt b, and NADHdehydrogenase subunit 4 - ND-4) and three nuclear genes (rhodopsin - Rhod, TMO-4C4, and RAG-1). Each PCR comprised a mix of deoxynucleotides (dNTPs) at 200 $\mu \mathrm{M}, 1 \mathrm{x}$ buffer, $\mathrm{MgCl}_{2}$ at $2 \mathrm{mM}, 0.4 \mu \mathrm{L}$ of each primer $(10$ $\mu \mathrm{M}), 0.06 \mathrm{U} / \mu \mathrm{L}$ of Taq DNA polymerase, about $50 \mathrm{ng}$ of template DNA and ultrapure water to a final volume of 15 $\mu \mathrm{L}$. The primers used to amplify each gene are described in Tab. 2.

The amplification conditions were: first denaturation step at $95^{\circ} \mathrm{C}$ for $5 \mathrm{~min}$., followed by 38 cycles of denaturation at $95^{\circ} \mathrm{C}$ for $30 \mathrm{sec}$., hybridization for $30 \mathrm{sec}$. (see temperature details for each primer pair in Tab. 2) and extension at $72^{\circ} \mathrm{C}$ for $2 \mathrm{~min}$., plus a final extension step at $72^{\circ} \mathrm{C}$ for $5 \mathrm{~min}$. The RAG-1 fragment was amplified using nested PCR, in which the first reaction used the primers RAG1-2510F (Li, Ortì, 2007) and RAG1-4090R (Lopez et $a l ., 2004)$, followed by a second reaction with the primers RAG1-2533F and RAG1-4078F (Lopez et al., 2004).

The amplicons were purified in PEG 8000 (polyethylene glycol) according to Paithankar, Prasad (1991) and submitted to dideoxi sequencing reaction (Sanger et al., 1977) using the Big Dye kit (ABI Prism ${ }^{T M}$ Dye Terminator Cycle Sequencing Reading Reaction - Applied Biosystems, USA). The fragments were bidirectionally amplified using specific forward and reverse primers. The final product was precipitated and sequenced in ABI 3500 automatic sequencer (Applied Biosystems).

Tab. 2. Primers, references and hybridization temperature used for mitochondrial and nuclear markers.

\begin{tabular}{|c|c|c|c|}
\hline Marker & Primers- 5'-3' & Reference & Hybridization $\left({ }^{\circ} \mathrm{C}\right)$ \\
\hline COI & $\begin{array}{l}\text { COIFishF1- TCAACCAACCACAAAGACATTGGCAC } \\
\text { COIA- AGTATAAGCGTCTGGGTAGTC }\end{array}$ & $\begin{array}{l}\text { Ward et al. (2005) } \\
\text { Palumbi, Benzie, (1991) }\end{array}$ & $\begin{array}{l}\text { 56, except for } L . \text { synagris, } L . \text { jocu, } L . \\
\text { alexandrei, L.cyanopterus, O. chrysurus and } \\
\text { C. nobilis (53.8). }\end{array}$ \\
\hline ND-4 & $\begin{array}{l}\text { NAP2- CAAAACCTTAATCTYCTACAATGCT } \\
\text { ND4LB- CAAAACCTTAATCTYCTACAATGCT }\end{array}$ & $\begin{array}{l}\text { Arevalo et al. (1994) } \\
\text { Bielawski, Gold (2002) }\end{array}$ & 56 \\
\hline Rhod & $\begin{array}{l}\text { RodF2W- AGCAACTTCCGCTTCGGTGAGAA } \\
\text { Rod4R- GGAACTGCTTGTTCATGCAGATGTAGAT }\end{array}$ & Sevilla et al. (2007) & 59 \\
\hline RAG-1 & $\begin{array}{l}\text { RAG12510F- TGGCCATCCGGGTMAACAC } \\
\text { RAG14090R- CTGAGTCCTTGTGAGCTTCCATRAAYTT } \\
\text { RAG12533F- CTGAGCTGCAGTCAGTACCATAAGATGT } \\
\text { RAG14078R- TGAGCCTCCATGAACTTCTGAAGRTAYTT }\end{array}$ & Lopez et al. (2004) & $\begin{array}{l}55 \text {, except for } O . \text { chrysurus, L. analis }(57) \text {; } \\
\text { L. purpureus, L. campechanus, L. buccanella } \\
\text { and L. synagris ( } 63) \text {. }\end{array}$ \\
\hline
\end{tabular}


Phylogenetic Analyses. The sequences from each gene were organized into individual datasets and edited in the software BioEdit (Hall, 1999). Visual inspection was carried out to correct the sequence position in cases of doubtful or misidentified nucleotides.

The alignment of the corrected sequence datasets was performed automatically in the online version of MAFFT (Katoh, Standley, 2013). The 3' and 5' ends were removed to discard unreadable sequence parts and to decrease the amount of missing data.

In the phylogenetic analysis to test the validation of Rhomboplites and Ocyurus, the data matrix comprised 4,481 base pairs (bp), being 2,983 pb from mtDNA (16S $=498 \mathrm{bp}, \mathrm{COI}=1,133 \mathrm{bp}, \mathrm{Cyt} \mathrm{b}=750 \mathrm{bp}, \mathrm{ND}-4=600$ $\mathrm{bp}$ ) and 1,500 bp from nuclear DNA (RAG-1 $=650 \mathrm{bp}$, Rhod $=420 \mathrm{bp}, \mathrm{TMO}-4 \mathrm{C} 4=430 \mathrm{bp}$ ). These markers were obtained from 24 specimens, including Lutjaninae species from WA, besides Etelis oculatus and Conodon nobilis.

The selection of the best scheme of partitions and the evolutionary models to explain the variation in sequences from each gene was performed in the PartitionFinder2 (Guindon et al., 2010; Lanfear et al., 2012; Lanfear et al., 2016) (Tab. 3).

Based on the multilocus dataset, we estimated the phylogenetic relationships among taxa based on maximum likelihood (ML) and Bayesian inference (BI). The ML tree was built using RAxML version 8.2 (Stamatakis, 2014) with the $G T R+G$ evolutionary model for each partition (see Tab. 3). The support of each branch was calculated using bootstrap with 1000 pseudoreplicates.

The BI was carried out in MrBayes, version 3.2 (Ronquist et al., 2011) using the previously selected evolutionary model for each partition (see Tab. 3).

Two independent runs with four $\mathrm{MC}^{3}$ chains were performed based on 10 million generations, with tree sampling at each 10,000 generations and $10 \%$ of burn-in. The chain convergence was evaluated in Tracer, version 1.6 (Rambaut et al., 2014) and the consensus tree was visualized and edited in FigTree, version 1.4.3 (Rambaut, 2016).

Tab. 3. Nucleotide substituition models selected by PartitionFinder for each gene partition, and their position in the alignment, for each phylogenetic analysis performed in the present study.

\begin{tabular}{|c|c|c|}
\hline \multicolumn{3}{|l|}{ RAXML } \\
\hline Model & Subset partitions & Subset sites \\
\hline $\mathrm{GTR}+\mathrm{G}$ & 16S, ND4_3, Rhod_1, TMO-4C4_1, RAG-1_2 & $1-498,2384-2981 \backslash 3,3632-4051 \backslash 3,4052-4481 \backslash 3,2983-3631 \backslash 3$ \\
\hline $\mathrm{GTR}+\mathrm{G}$ & COI_1, CytB_3, ND4_2 & $499-1631 \backslash 3,1634-2381 \backslash 3,2383-2981 \backslash 3$ \\
\hline $\mathrm{GTR}+\mathrm{G}$ & Rhod_2, RAG-1_3, TMO-4C4_2, CytB_1, COI_2 & $3633-4051 \backslash 3,2984-3631 \backslash 3,4053-4481 \backslash 3,1632-2381 \backslash 3,500-1631 \backslash 3$ \\
\hline $\mathrm{GTR}+\mathrm{G}$ & TMO-4C4_3, RAG-1_1, Rhod_3, ND4_1, COI_3, CytB_2 & $4054-4481 \backslash 3,2982-3631 \backslash 3,3634-4051 \backslash 3,2382-2981 \backslash 3,501-1631 \backslash 3,1633-2381 \backslash 3$ \\
\hline \multicolumn{3}{|l|}{ Mr Bayes } \\
\hline $\mathrm{K} 80+\mathrm{G}$ & TMO4-4C4_1, 16S, ND4_3 & $4052-4481 \backslash 3,1-498,2384-2981 \backslash 3$ \\
\hline $\mathrm{GTR}+\mathrm{G}$ & COI_1, CytB_3, ND4_pos2 & $499-1631 \backslash 3,1634-2381 \backslash 3,2383-2981 \backslash 3$ \\
\hline $\mathrm{K} 81+\mathrm{I}$ & COI_2, CytB_1, RAG-1_1 & $500-1631 \backslash 3,1632-2381 \backslash 3,2982-3631 \backslash 3$ \\
\hline $\mathrm{F} 81+\mathrm{I}$ & TMO-4C4_3, Rhod_3, COI_3, ND4_1, CytB_2 & $4054-4481 \backslash 3,3634-4051 \backslash 3,501-1631 \backslash 3,2382-2981 \backslash 3,1633-2381 \backslash 3$ \\
\hline HKY & Rhod_1, RAG-1_2 & $3632-4051 \backslash 3,2983-3631 \backslash 3$ \\
\hline F81 & TMO-4C4_2, RAG-1_3 & $4053-4481 \backslash 3,2984-3631 \backslash 3$ \\
\hline TRNEF+I & Rhod_2 & $3633-4051 \backslash 3$ \\
\hline \multicolumn{3}{|c|}{ Beast - Divergence time } \\
\hline $\mathrm{HKY}+\mathrm{G}$ & $16 \mathrm{~S}, \mathrm{ND} 4 \_3$ & $1-498,2384-2981 \backslash 3$ \\
\hline $\mathrm{GTR}+\mathrm{G}$ & COI_1, Cytb_3, ND4_2 & $499-1631 \backslash 3,1634-2381 \backslash 3,2383-2981 \backslash 3$ \\
\hline $\mathrm{TRN}+\mathrm{I}$ & CytB_1, COI_2 & $1632-2381 \backslash 3,500-1631 \backslash 3$ \\
\hline HKY & COI_3, ND4_1, CytB_2 & $501-1631 \backslash 3,2382-2981 \backslash 3,1633-2381 \backslash 3$ \\
\hline HKY & Rhod_3, RAG-1_1, TMO-4C4_3 & $653-1070 \backslash 3,1-650 \backslash 3,1073-1500 \backslash 3$ \\
\hline $\mathrm{HKY}+\mathrm{G}$ & Rhod_pos1, RAG-1_2, TMO-4C4_1 & $651-1070 \backslash 3,2-650 \backslash 3,1071-1500 \backslash 3$ \\
\hline $\mathrm{HKY}+\mathrm{I}$ & Rhod_pos2, TMO-4C4_2, RAG-1_3 & $652-1070 \backslash 3,1072-1500 \backslash 3,3-650 \backslash 3$ \\
\hline \multicolumn{3}{|c|}{ Beast - *Beast } \\
\hline $\mathrm{GTR}+\mathrm{G}$ & $16 \mathrm{~S}$ & $1-504$ \\
\hline $\mathrm{TRN}+\mathrm{G}$ & COI_1 & $505-1637 \backslash 3$ \\
\hline $\mathrm{TRN}+\mathrm{I}$ & RAG-1_3, COI_2, CytB_1, RAG-1_1 & $2390-3037 \backslash 3,506-1637 \backslash 3,1638-2387 \backslash 3,2388-3037 \backslash 3$ \\
\hline $\mathrm{HKY}+\mathrm{I}$ & COI_3, CytB_2 & $507-1637 \backslash 3,1639-2387 \backslash 3$ \\
\hline $\mathrm{GTR}+\mathrm{G}$ & CytB_3 & $1640-2387 \backslash 3$ \\
\hline $\mathrm{HKY}+\mathrm{G}$ & RAG-1_2 & $2389-3037 \backslash 3$ \\
\hline
\end{tabular}


We also used a multi-species coalescent approach to estimate a species tree using the *BEAST option, available in BEAST v. 1.8.1 (Drummond et al., 2012). The runs were made using a relaxed lognormal clock, Yule Process as tree prior, 400 million of steps, with sampling at 10,000 and using $20 \%$ of burn-in. The choice of the optimal partition scheme and evolutionary models were made in PartitionFinder2 (Guindon et al., 2010; Lanfear et al., 2012; Lanfear et al., 2016) (see Tab. 3). The *BEAST runs were conducted in the CIPRES Science Gateway V. 3.3 (Miller et al., 2010). The mixing and convergence of runs were checked in Tracer, version 1.6 (Rambaut et al., 2014), and the consensus tree was made in the Beast v. 1.8.1 application "treeannotator", visualized and edited in FigTree, version 1.4.3 (Rambaut, 2016).

Divergence time of lineages. To infer the time of diversification among lineages that gave rise to $L$. alexandrei, as well as its phylogenetic position in Lutjanidae, we analyzed a more extensive dataset, including the collected samples of snappers from this study (previously used in ML and BI analyses) as well as the available sequences in Genbank analyzed by Frédérich, Santini (2017), and the sequences provided by Gold et al. (2011) from a non-identified species ( $L$. cf. apodus). Therefore, the data matrix encompassed 48 specimens and 3,037 characters represented by 504 bp of $16 \mathrm{~S}$; 1,133 bp of COI; $750 \mathrm{bp}$ of Cyt b, and $650 \mathrm{bp}$ of RAG-1 (see Tab. 1).

The calibration of the divergence period was based on the divergence time between Lutjanidae and Haemulidae (67 Mya \pm 10 S. D; Frédérich, Santini, 2017) and on the data estimated for the diversification of "Lutjanus", according to the minimum age of the most ancient fossil reported for this family (Hypsocephalus atlanticus Swift, Ellwood, 1972) data between 33.9 and 50 Mya (Frédérich, Santini, 2017). Since this fossil is considered a close relative of Hoplopagrus guntherii (Gill, 1862), a taxon that has been recovered within Lutjanus, this fossil dating was employed to determine the minimum age of Lutjanus (Frédérich, Santini, 2017).

The diversification analysis was carried out in BEAST v. 1.8.4 (Drummond et al., 2012) using the CIPRES Science Gateway V. 3.3 (Miller et al., 2010) based on 200 million generations, relaxed log-normal clock, and the evolutionary models and partitions selected by PartitionFinder2 using the "greedy algorithm" (Guindon et al., 2010; Lanfear et al., 2012; Lanfear et al., 2016) (see Tab. 3). Genealogies were sampled at each 10,000 generations using $10 \%$ of burn-in. The chain convergence was inspected using the software Tracer, version 1.6 (Rambaut et al., 2014) and the consensus tree was visualized and edited in FigTree, version 1.4.3 (Rambaut, 2016).

\section{Results}

The multiloci phylogenetic inferences herein performed for Lutjaninae species from WA comprised the highest number of loci in Lutjanidae phylogenies so far
(4.4 kb). The topologies of ML, BI, and species trees were very similar and thereby we only show the BI topology, including the support values of the three analyses (Fig. 1).

The clade A supports the monophyly of studied Lutjaninae, that is, for Lutjaninae species from WA included in this analysis. The clade B comprises two major lineages: one of them diverges giving rise to the clade $\mathrm{D}$, composed of L. cyanopterus and clade C ( $L$. jocu and L. alexandrei), while the other diversifies into clade $\mathrm{E}$, encompassing the remaining taxa from this study. Within this group, the $L$. synagris $+L$. analis branch (clade $\mathrm{F}$ ) is a sister group of clade that contains $R$. aurorubens and $O$. chrysurus, which is further related to and L. purpureus, L. campechanus, $L$. vivanus, and $L$. buccanella that appear to be closely related being named as clade G. All these clades were characterized by high probability values ( 0.99 or 1$)$, except for clade $\mathrm{D}(0.96)$, and the branch that groups O. chrysurus and $R$. aurorubens (0.50). However, the bootstrap values in ML inference were more strict (see Fig. 1).

With regard to the phylogenetic positioning of $L$. alexandrei in Lutjanidae, according to the BI based on a dataset of $3.0 \mathrm{~kb}$ and 40 species of Lutjanidae, $L$. alexandrei is the sister group of $L$. apodus, forming a well supported clade. This clade is reciprocally monophyletic to $L$. griseus and $L$. jocu that, altogether, are closely related to L. cyanopterus + L. argentimaculatus (Forsskal, 1775) (Fig. 2).

Based on the present results, the diversification of the lineage that gave rise to the Brazilian snapper has begun between $4.5-9.2$ Mya in Pliocene, while the $L$. alexandrei $+L$. apodus pair diverged between $2.5-6.5$ Mya. The diversification of $L$. griseus and $L$. jocu occurred simultaneously between 2.9-7.3 Mya.

\section{Discussion}

Phylogenetic relationships of Lutjaninae species from Western Atlantic. The monophyly recovered for Lutjaninae species from WA included in the study confirms the findings reported by Gold et al. (2011) based on mtDNA (cyt b, COI and ND-4). On the other hand, if we consider any subfamily, and not only WA species, other molecular studies considered that the status of this subfamily as a natural group is questionable. For instance, analyses using 16S rRNA, cyt b, ND-4 and COI mitochondrial genes placed Caesionidae within Lutjaninae (Miller, Cribb, 2007; Chu et al., 2013; Gold et al., 2015). Similarly, Frédérich, Santini (2017) indicated that Lutjaninae is a non-monophyletic group inasmuch as all genera of fusiliers (regarded as a subfamily of Lutjanidae by these authors) were closely related to the former. In fact, the inclusion of Caesionidae within Lutjanidae has already been evidenced by morphological analyses (Johnson, 1993; Nelson, 1994) and corroborated by molecular data (Betancur-R et al., 2013), which in the present study is also reported (see Fig. 2). 


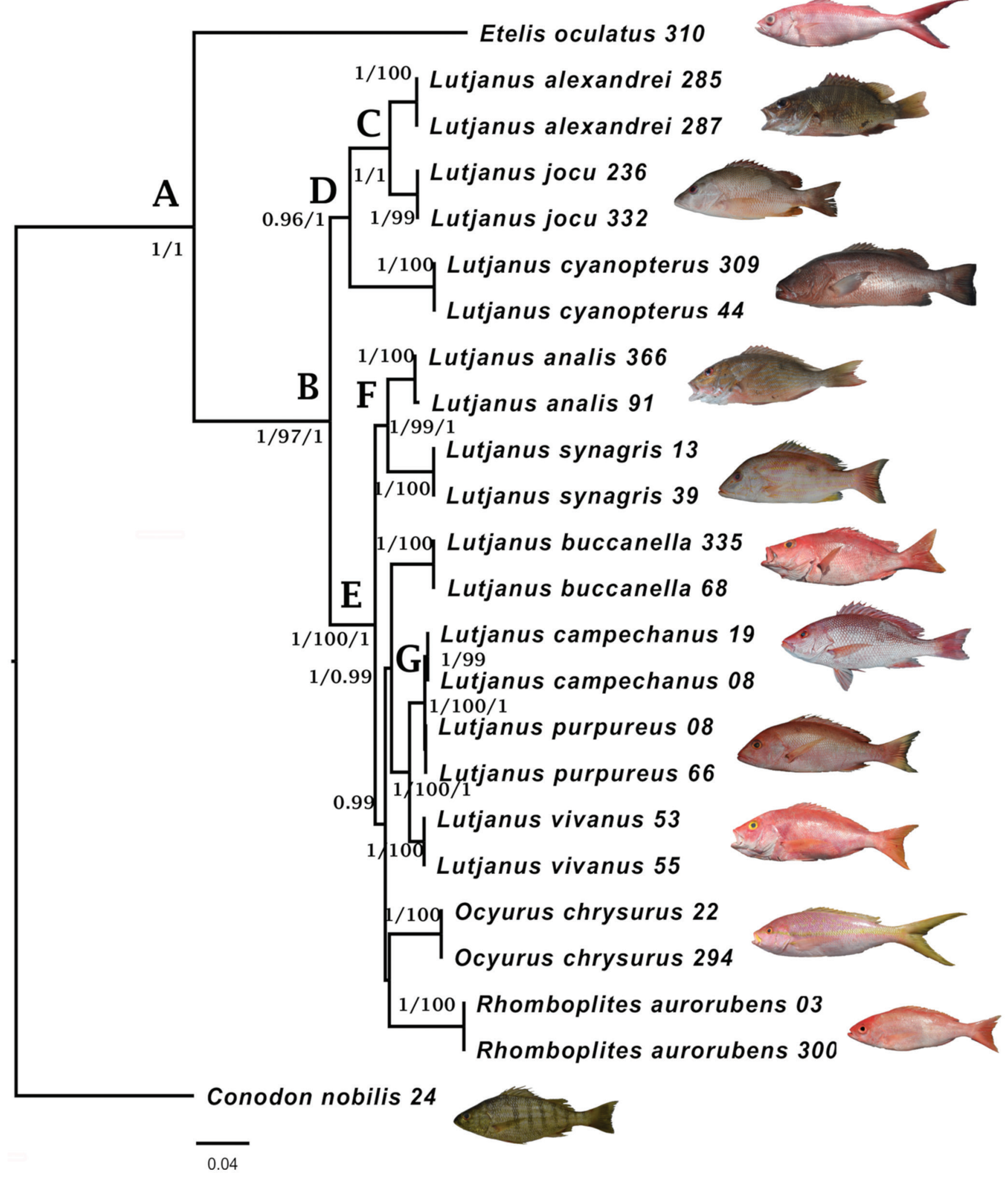

Fig. 1. Phylogenetic relationships in Lutjaninae species from the Western Atlantic estimated by Bayesian (BI), maximum likelihood (ML) and a Species Tre analyses inferences based on a data matrix (4.4 kb) comprising mitochondrial (16S rRNA, COI, cyt b, and ND-4) and nuclear (Rhodopsin, TMO4C4 and RAG-1) markers. The BI topology is presented with the posterior probability (BI and Species Tree) and bootstrap (ML) values. The letters in the nodes refer to the clades discussed in the text. 


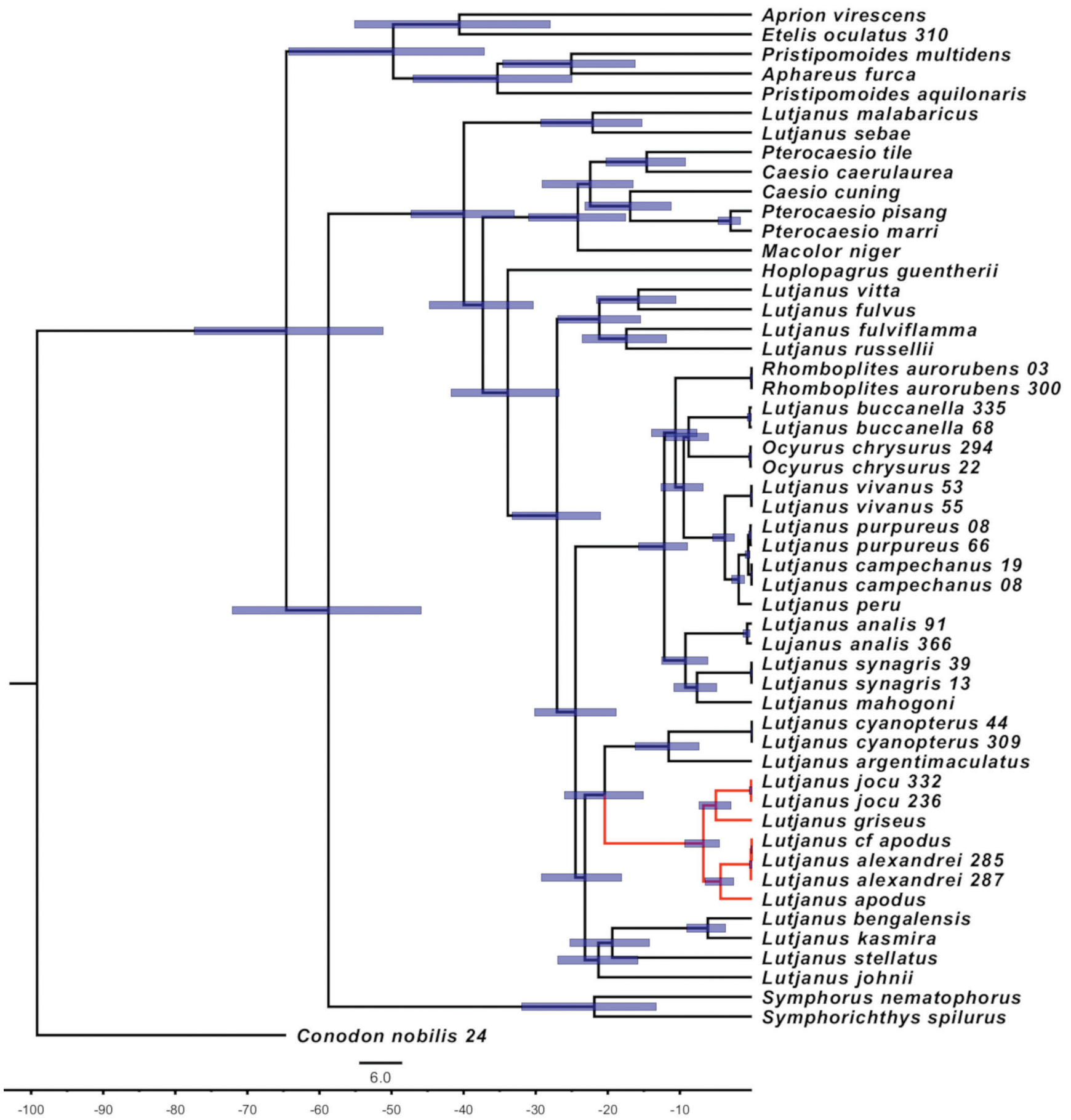

Fig. 2. Bayesian inference based on the $3.0 \mathrm{~kb}$ dataset of mtDNA (16S, COI, and cyt b) and nuclear (RAG-1) sequences in 40 Lutjanidae species. The dating was based on the estimated minimum age for the oldest fossil reported to the family. The branch mainly discussed in the text is highlighted, revealing the origin of Lutjanus alexandrei between $2.5-6.5$ Mya.

Lutjanus alexandrei, placed as a sister group of $L . j o c u$, is a recently described species (Moura, Lindeman, 2007), endemic to the Brazilian coast that lack previous phylogenetic inferences. The clade $\mathrm{C}$ herein reported $(L . j o c u+L$. alexandrei $)$ agrees with the results from Gold et al. (2011) and Gold et al. (2015) that recovered a close relationship among $L$. jocu, $L$. griseus, $L$. apodus and $L$. cf. apodus, since the latter is likely to represent $L$. alexandrei, as suggested by Gold et al. (2011).
The taxa included in clade $G$ ( $L$. purpureus, $L$. campechanus, L. vivanus, and L. buccanella) is partly consistent with the phenetic classification of Lutjaninae, divided into grey snappers (L. griseus, L. apodus, L. jocu, and L. cyanopterus) and the "Lutjanus analis" group or red snappers (L. analis, L. purpureus, L. vivanus, $L$. campechanus, and L. buccanella) (Rivas, 1966; Vergara, 1980). 
Based on molecular data, Sarver et al. (1996) proposed a phylogenetic hypothesis for 12 species of Lutjanidae from WA using concatenated information of two mitochondrial genes (12S rRNA and cyt $b$ ). Similarly to our results, these authors also reported a partial correspondence with the phenetic groups of snappers, as also supported in recent phylogenies for this family (Gold et al., 2011; Gold et al., 2015; Frédérich, Santini, 2017).

Nonetheless, taking into account the first sample set, the present results differ from other studies (Sarver et al., 1966; Gold et al., 2011) in relation to L. analis, herein grouped with $L$. synagris (clade F). In addition, L. cyanopterus, here, groups together with $L$. jocu and L. alexandrei (clade D), corroborating the grey snapper group of the phenetic classification (Rivas, 1966; Vergara, 1980). But, other studies with snappers from WA report that $L$. cyanopterus is not closely related to any other studied species in this Atlantic region (Sarver et al., 1966; Gold et al., 2011). As commonly observed for many other Lutjaninae species from WA, the putative sister taxon of $L$. cyanopterus is $L$. novemfasciatus (Gill, 1862), a native species from Pacific Ocean (Chu et al., 2013; Gold et al., 2015; Frédérich, Santini, 2017).

The relationships in the clade $\mathrm{F}$ and in the clade $\mathrm{D}$, apparently discordant with previous studies (Sarver et al., 1966; Gold et al., 2011), are in fact the result of the more limited sampling of the first sample set analyzed, therefore analyzing the second sample set, the relationships between L. synagris, L. mahogoni and L. analis, as well as among gray snapper, resemble results already reported (Chu et al., 2013, Frédérich, Santini, 2017).

The controversial taxonomic status of Rhomboplites and Ocyurus. Rhomboplites aurorubens and Ocyurus chrysurus were included in clade $\mathrm{E}$ along with other Lutjanus species, thus reaffirming the paraphyletic status of this genus. This result brings back a long debate about the inclusion of Rhomboplites and Ocyurus in Lutjanus.

These two monotypic genera were recognized by Gill (1862) that differed them from Lutjanus based on the following traits: the forked caudal fin with thin lobes in Ocyurus and the presence of a rhomboid vomerine tooth in Rhomboplites versus more or less truncate caudal fin and triangular vomerine tooth in Lutjanus (Gill, 1862). Nonetheless, more extensive and recent studies revealed that the vomerine teeth in Lutjanus species might range from "V"-shape to rhomboid or anchor-like shape (Cervigón, 1993; Anderson, 2002; Claro, Lindeman, 2008).

Other morphological traits that have been used to differentiate both monotypic genes from Lutjanus include the number of gill rakers (lower in Lutjanus) and the presence of ectopterygoid teeth (absent in Lutjanus) (Cervigón, 1993; Anderson, 2002). Rhomboplites is also diagnosed by the number of spines in dorsal fins $(n=12)$ while Lutjanus species present 10 to 11 spines (Cervigón, 1993; Claro, Lindeman, 2008).
On the other hand, phylogenetic inferences based on morphometrics, biochemistry (Chow, Walsh, 1992), and molecular data (Sarver, Freshwater, Walsh, 1996; Gold et al., 2011; Gold et al., 2015; Frédérich, Santini, 2017) revealed that these genera diverged from distinct lineages but closely related to Lutjanus red snappers, as observed in clade E.

Accordingly, Sarver et al. (1996) proposed the synonymy between the genera Ocyurus and Lutjanus inasmuch as $O$. chrysurus is clustered along other Lutjanus species a pattern also observed in relation to Rhomboplites, but not mentioned by the authors. Likewise, the phylogenetic trees reported by Miller, Cribb (2007) also recovered $R$. aurorubens within the Lutjanus lineage.

In a comparative approach, Gold et al. (2011) showed that both $R$. aurorubens and $O$. chrysurus are placed along with Lutjanus in the phylogenetic trees, thereby suggesting the reallocation of these species in the genus Lutjanus. These authors stated that most of the distinctive morphological features might represent differential adaptation to feeding thereby representing homoplasies while the chromosomal peculiarities reported by Nirchio et al. (2009) between Rhomboplites and Lutjanus could be autapomorphic since few species have been cytogenetically analyzed. Moreover, they pointed out that the weak support of the branches related to $O$. chrysurus and $R$. aurorubens might reflect fast speciation processes that are hardly identified by mtDNA markers only (Zink, Barrowclough, 2008).

Only recently, Frédérich, Santini (2017) published a study about the time and mode of diversification in Lutjanidae based on fossil calibration that encompassed $70 \%$ of their actual diversity and a single nuclear gene (RAG-1). The authors hypothesized that the remarkable distinct ecological traits between Lutjanus and other closely related lineages (e.g., peculiar food preferences, occurrence at differential depths and specific life history strategies) may be the result of fast and recent adaptive radiation, differently from the pattern usually reported for reef-associated fish. Furthermore, this report also placed Rhomboplites and Ocyurus along with Lutjanus species, reinforcing this genus as a non-monophyletic group (Frédérich, Santini, 2017).

Taking into account that our results corroborated several reports that reveal the high genetic affinities between Lutjanus, Rhomboplites and Ocyurus, and that the morphological differences among these putative genera are subtle and mostly derived from ecological adaptation, we consider that there is sufficient evidence to allocate these monotypic genera within Lutjanus. Even though, the monophyly of the genus remains unsolved and should be investigated by integrative studies, since the grouping of Lutjanus with other genera of Lutjaninae and Caesioninae have also been indicated (Chu et al., 2013; Frédérich, Santini, 2017).

Phylogenetic position and divergence time of $L$. alexandrei. After the description of L. alexandrei (Moura, Lindeman, 2007), this species has been studied in relation to reproduction (Fernandes et al., 2012), aging, growth, mortality 
(Aschenbrenner, Ferreira, 2015), and cytogenetics (Rocha, Molina, 2008). However, the phylogenetic relationships and the origin of this species remained unknown.

The relationships recovered in BI for $L$. alexandrei, $L$. apodus, L. jocu and L. griseus are consistent with previous inferences (Sarver et al., 1996; Gold et al., 2011; Chu et al., 2013; Gold et al., 2015; Frédérich, Santini, 2017), the present study stands out by the inclusion of $L$. alexandrei that was selected for dating inferences.

The phylogenetic analysis by Gold et al. (2011) included a non-identified species of Lutjanus (L. cf. apodus), placed as a sister taxon of $L$. apodus, and related to both $L$. jocu and L. griseus. According to these authors, this specimen could represent $L$. alexandrei since it was collected in northeastern Brazil, has proved to be evolutionary related to the abovementioned species, and presented morphological traits similar to those reported by Moura, Lindeman (2007). The relationships herein presented in this clade agree with the reports by Gold et al. (2011) and Gold et al. (2015), allowing us to confirm that $L$. cf. apodus cited in both studies actually corresponds to L. alexandrei.

Our estimates of time for the diversification events that led to the L. alexandrei lineage were similar to the ranges recorded by Gold et al. (2011) for the L. apodus $+L$. cf. apodus $(=L$. alexandrei) pair as well as for the cluster that comprises both taxa, even though these authors used calibration based on the molecular evolutionary rate of cyt b marker while we relied on fossil dating as carried out by Frédérich, Santini (2017).

The Pliocene was a period of low tectonism preceded by volcanic activities that formed the western arch of Lesser Antilles islands in the Caribbean Sea. In addition, the uplift of the Isthmus of Panama has possibly intensified the Gulf Current, thus leading to a greater flow of warm waters to the regions southern to the Caribbean (Gold et al., 2011).

The second diversification event that has probably been responsible for the separation between $L$. apodus and $L$. alexandrei should be related to the $2,300 \mathrm{~km}$ muddy outflow from the Amazonas and Orinoco rivers in the coastal region of South America that prevented the formation of coral reefs thus acting as a putative barrier (Gold et al., 2011). Indeed, in their description of L. alexandrei, the authors emphasized the importance of the freshwater discharges from both rivers in population isolation and allopatric speciation between the Caribbean and most of South America coast (Moura, Lindeman, 2007).

For the separation of L. apodus and L. griseus we were also in agreement with Gold et al. (2011). The species that take part of this clade share some ecological traits, including the preference for estuarine environments for reproduction and during juvenile stages (Cervigón, 1993; Moura, Lindeman, 2007; Claro, Lindeman, 2008).

In their description of L. alexandrei, Moura, Lindeman (2007) discuss the validation of the occurrence of L. apodus and L. griseus in Brazil, once the specimens formerly recognized as both taxa available in museums, photographic records, voucher material and collections along estuarine and reef areas of Brazilian coast invariably corresponded to the new species identified by these authors. Therefore, the native range of $L$. apodus and L. griseus would be restricted from Massachusetts to the Caribbean Sea, while the Brazilian snapper should be endemic to northeastern Brazil, from Maranhão to Bahia coast, being sympatric to $L$. jocu, thus leading to their misidentification (Moura, Lindeman, 2007). Nonetheless, L. jocu is widespread from the USA coast to northeastern Brazil (Allen, 1985; Cervigón, 1993).

The apparent absence of $L$. alexandrei in the estuaries from the northern Brazilian coast might be related to ecological features such as the low tolerance of this species to salinity variation when compared to $L$. jocu, a species that can be adapted to riverine habitats with salinity levels above 40\% (Claro, Lindeman, 2008). Therefore, even though both species depend on the estuarine environments during early life cycles, $L$. jocu is able to inhabit estuaries from northern Brazil which are characterized by remarkable salinity fluctuations influences by the outflow of large rivers from Amazon, with salinity levels close to zero during rainy seasons (Barletta-Bergan et al., 2002; Barletta et al., 2005; Asp et al., 2016). On the other hand, the estuaries from northeastern Brazil are characterized by high salinity levels (Schwamborn et al., 2001; Araujo, 2006; Silva et al., 2009).

Similar ecological features are reported between $L$. jocu and L. griseus and L. alexandrei and L. apodus, respectively, since juveniles of L. griseus are commonly found in brackish and nearly freshwater estuarine waters as well as in hypersaline waters, an adaptation that is not observed in $L$. apodus (Cervigón, 1993; Claro, Lindeman, 2008).

In relation to $O$. chrysurus and $R$. aurorubens, several reports have already indicated that both taxa should be included within Lutjanus. Nevertheless, some authors considered that the morphological differences among them would be enough to their allocation into distinct genera, even though today we currently acknowledge that that such differences may reflect adaptation processes that have probably arisen several times throughout their evolution, thus representing homoplasies.

On the other hand, molecular studies have refuted the validation of both monotypic genera of Lutjanidae, even though they were based only on mitochondrial markers, which jeopardize this inference. However, a recent phylogenetic study included a single nuclear gene also demonstrated the overestimated status of Rhomboplites and Ocyurus as distinct genera. In the present study, we evaluated a higher number of nuclear and mitochondrial genes, thus providing additional support to the synonymy of these genera and Lutjanus, besides reinforcing the apparent non-monophyletic status of the latter.

Therefore, the adaptive radiation of snapper and fisiliers should be further investigated, since a single report focused this aspect (Frédérich, Santini, 2017). Studies like this could be helpful to explain and organize the diversity of Lutjanidae.

As for L. alexandrei, this is the first report, comprising the largest and most reliable molecular dataset so far, that inferred, unequivocally, the phylogenetic relationships 
of this species in relation to other lutjanids. The Brazilian snapper, endemic from the northeastern coast, and L. apodus represent sister taxa that diverged between 2.5-6.5 Mya, as a result of the vicariance caused by the outflow of Amazon rivers between the actual range of both species.

\section{Acknowledgments}

This research was supported by the Conselho Naciomal de Desenvolvimento Científico e Tercnológico $(\mathrm{CNPq})$ in the form of master's scholarship on behalf of Ivana Veneza and research grants on behalf of Iracilda Sampaio (number 306233/2009-6) and Horacio Schneider (number 306233/2009-6).

\section{References}

Allen GR. Snappers of the world: an annotated and illustrated catalogue of lutjanid species known to date. Rome: FAO; 1985. (FAO species catalogue. FAO Fisheries Synopsis; No. 125, vol 6). Anderson WD, Jr. Suborder Percoidei: Lutjanidae. In: Carpenter $\mathrm{KE}$, editor. The living marine resources of the Western Central Atlantic - Volume 3: bony fishes part 2 (Opistognathidae to Molidae), sea turtles and marine mammals. Rome: FAO; 2002. (FAO Species Identification Guide for Fishery Purposes and American Society of Ichthyologists and Herpetologists. Special Publication; No. 5). p.1479-1504.

Araujo HMP. Distribution of Paracalanidae species (Copepoda, Crustacea) in the continental shelf off Sergipe and Alagoas states, Northeast Brazil. Braz J Oceanogr. 2006; 54(4):173-81.

Arèvalo E, Davis SK, Sites JW, Jr. Mitochondrial DNA sequence divergence and phylogenetic relationships among eight chromosome races of the Sceloporus grammicus complex (Phrynosomatidae) in Central Mexico. Syst Biol. 1994; 43(3):387-418.

Aschenbrenner A, Ferreira BP. Age, growth and mortality of Lutjanus alexandrei in estuarine and coastal watersof the tropical southwestern Atlantic. J Appl Ichthyol. 2015; 31(1):57-64.

Asp NE, Gomes VJC, Ogston A, Borges JCC, Nittrouer CA. Sediment source, turbidity maximum, and implications for mud exchange between channel and mangroves in an Amazonian estuary. Ocean Dyn. 2016; 66(2):285-97.

Barletta M, Barletta-Bergan A, Saint-Paul U, Hubold G. The role of salinity in structuring the fish assemblages in a tropical estuary. $\mathrm{J}$ Fish Biol. 2005; 66(1):45-72.

Barletta-Bergan A, Barletta M, Saint-Paul U. Structure and seasonal dynamics of larval fish in the Caeté river estuary in North Brazil. Estuar Coast Shelf Sci. 2002; 54(2):193-206.

Betancur-R R, Broughton RE, Wiley EO, Carpenter K, López JA, Li $\mathrm{C}$ et al. The tree of life and a new classification of bony fishes. PLoS Curr. 2013.

Bielawski JP, Gold JR. Mutation patterns of mitochondrial H- and L-strand DNA in closely related Cyprinid fishes. Genetics. 2002; 161(4):1589-97.

Cervigón F. Los peces marinos de Venezuela. Caracas: Fundación Científica Los Roques; 1993. (Fundación Científica Los Roques; vol 2).
Chow S, Walsh PJ. Biochemical and morphometric analyses for phylogenic relationships between seven snapper species (Subfamily Lutjaninae) of the Western Atlantic. Bull Mar Sci. 1992; 50(3):508-19.

Chu C, Rizman-Idid M, Ching CV. Phylogenetic relationships of selected genera of Lutjanidae inferred from mitochondrial regions, with a note on the taxonomic status of Pinjalo pinjalo. Cienc Mar. 2013; 39(4):349-61.

Claro R, Lindeman KC. Biología y manejo de los pargos (Lutjanidae) en el Atlántico Occidental. La Habana: Instituto de Oceanología; 2008.

Drummond AJ, Suchard MA, Xie D, Rambaut A. Bayesian phylogenetics with BEAUti and the BEAST 1.7. Mol Biol Evol. 2012; 29(8):1969-73.

Eschmeyer WN, Fricke R, van der Laan R, editors. Catalog of fishes: genera, species, references [Internet]. San Francisco: California Academy of Sciences; 2018 [updated 2018 Jul 2; cited 2018 Jul 27]. Available from: http://researcharchive. calacademy.org/research/ichthyology/catalog/fishcatmain.asp

Evermann BW, Marsh MC. The fishes of Porto Rico. Bull US Bur Fish Comm. 1900; 20(1):49-402.

Farias IP, Ortí G, Meyer A. Total evidence: molecules, morphology, and the phylogenetics of cichlid fishes. J Exp Zool B Mol Dev Evol. 2000; 288(1):76-92.

Fernandes CAF, Oliveira PGV, Travassos PEP, Hazin FHV. Reproduction of the brazilian snapper, Lutjanus alexandrei Moura, Lindeman, 2007 (Perciformes: Lutjanidae), off the northern coast of Pernambuco, Brazil. Neotrop Ichthyol. 2012; 10(3):587-92

Frédérich B, Santini F. Macroevolutionary analysis of the tempo of diversification in snappers and fusiliers (Percomorpha: Lutjanidae). Belg J Zool. 2017; 147(1):17-35.

Gill T. Remarks on the relations of the genera and other groups of cuban fishes. Proc Acad Nat Sci Philad. 1862; 14(1862):235-42.

Gold JR, Voelker G, Renshaw MA. Phylogenetic relationships of tropical western Atlantic snappers in subfamily Lutjaninae (Lutjanidae: Perciformes) inferred from mitochondrial DNA sequences. Biol J Linn Soc. 2011; 102(4):915-29.

Gold JR, Willis SC, Renshaw MA, Buentello A, Walker HJ, Jr., Puritz JB et al. Phylogenetic relationships of tropical eastern Pacific snappers (Lutjanidae) inferred from mitochondrial DNA sequences. Syst Biodivers. 2015; 13(6):596-607.

Guindon S, Dufayard JF, Lefort V, Anisimova M, Hordijk W, Gascuel O. New algorithms and methods to estimate maximumlikelihood phylogenies: assessing the performance of PhyML 3.0. Syst Biol. 2010; 59(3):307-21.

Hall TA. BioEdit: a user-friendly biological sequence alignment editor and analysis program for Windows 95/98/NT. Nucleic Acids Symp Ser. 1999; 41:95-98.

Hastings PA, Walker HJ, Galland GR. Fishes: a guide to their diversity. Oakland, CA: University of California Press; 2014.

Johnson GD. Percomorph phylogeny: progress and problems. Bull Mar Sci. 1993; 52(1):3-28.

Katoh K, Standley DM. MAFFT multiple sequence alignment software version 7: improvements in performance and usability. Mol Biol Evol. 2013; 30(4):772-80. 
Lanfear R, Calcott B, Ho SYW, Guindon S. PartitionFinder: combined selection of partitioning schemes and substitution models for phylogenetic analyses. Mol Biol Evol. 2012; 29(6):1695-701.

Lanfear R, Frandsen PB, Wright AM, Senfeld T, Calcott B. PartitionFinder 2: new methods for selecting partitioned models of evolution formolecular and morphological phylogenetic analyses. Mol Biol Evol. 2017; 34(3):772-73.

López JA, Chen WJ, Ortì G. Esociform phylogeny. Copeia. 2004; 2004(3):449-64.

Miller MA, Pfeiffer W, Schwartz T. Creating the CIPRES Science Gateway for inference of large phylogenetic trees. In: 2010 Gateway Computing Environments Workshop (GCE). 2010. p.1-8.

Miller TL, Cribb TH. Phylogenetic relationships of some common Indo-Pacific snappers (Perciformes: Lutjanidae) based on mitochondrial DNA sequences, with comments on the taxonomic position of the Caesioninae. Mol Phylogenet Evol. 2007; 44(1):450-60

Ministério da Pesca e Aquicultura (MPA). Boletim estatístico da pesca e aquicultura: Brasil 2008-2009 [Internet]. Ministério da Pesca e Agricultura; 2009. Available from: http://www.icmbio. gov.br/cepsul/images/stories/biblioteca/download/estatistica/ est_2008_2009_nac_pesca.pdf

Ministério da Pesca e Aquicultura (MPA). Boletim estatístico da pesca e aquicultura: Brasil 2010. Ministério da Pesca e Agricultura; 2010.

Ministério da Pesca e Aquicultura (MPA). Boletim estatístico da pesca e aquicultura: 2011 [Internet]. Ministério da Pesca e Agricultura; 2011. Available from: http:/www.icmbio.gov. br/cepsul/images/stories/biblioteca/download/estatistica/ est_2011_bol_bra.pdf

Moura RL, Lindeman KC. A new species of snapper (Perciformes: Lutjanidae) from Brazil, with comments on the distribution of Lutjanus griseus and L. apodus. Zootaxa. 2007; 1422:31-43.

Nanami A, Yamada H. Seasonality, lunar periodicity of settlement and microhabitat association of juvenile humpback red snapper Lutjanus gibbus (Lutjanidae) in an Okinawan coral reef. Mar Biol. 2009; 156(3):407-14.

Near TJ, Dornburg A, Eytan RI, Keck BP, Smith WL, Kuhn KL et al. Phylogeny and tempo of diversification in the superradiation of spiny-rayed fishes. Proc Nat Acad Sci USA. 2013; 110(31):12738-43.

Nelson JS, Grande TC, Wilson MVH. Fishes of the world. 5th ed. New Jersey: John Wiley \& Sons; 2016.

Nelson JS. Fishes of the world. 3th. New York: John Wiley \& Sons; 1994.

Nirchio M, Oliveira C, Ferreira DC, Rondón R, Pérez JE, Rett $\mathrm{AK}$ et al. Cytogenetic characterization of Rhomboplites aurorubens and Ocyurus chrysurus, two monotypic genera of Lutjaninae from Cubagua Island, Venezuela, with a review of the cytogenetics of Lutjanidae (Teleostei: Perciformes). Neotrop Ichthyol. 2009; 7(4):587-94.

Paithankar KR, Prasad KS. Precipitation of DNA by polyethylene glycol and ethanol. Nucleic Acids Res. 1991; 19(6):1346[1p.].
Palumbi SR, Benzie J. Large mitochondrial DNA differences between morphologically similar Penaeid shrimp. Mol Mar Biol Biotechnol. 1991; 1(1):27-34.

Palumbi SR, Martin A, Romano S, McMillan WO, Stice L, Grabowski G. The simple fool's guide to PCR. Honolulu: University of Hawaii; 1991.

Rambaut A, editor. FigTree v 1.4.3. 2016. [Internet]; 2016 [updated 2016 Apr 10; cited 2018 Jan 27]. Available from: http://tree. bio.ed.ac.uk/software/figtree/

Rambaut A, Suchard MA, Xie W, Drummond AJ, editors. Tracer MCMC trace analysis tool v 1.6 [Internet]. 2014 [updated 2013 Dec 11; cited 2018 Jan 28]. Available from: http://tree.bio. ed.ac.uk/software/tracer/

Rivas LR. Review of the Lutjanus campechanus complex of red snappers. Quart J Fla Acad Sci. 1966; 29(2):117-36.

Rocha EC, Molina WF. Cytogenetic analysis in western Atlantic snappers (Perciformes, Lutjanidae). Genet Mol Biol. 2008; 31(2):461-67.

Ronquist F, Teslenko M, van der Mark P, Ayres DL, Darling A, Höhna $\mathrm{S}$ et al. MrBayes 3.2: efficient Bayesian phylogenetic inference and model choice across a large model space. Syst Biol. 2012; 61(3):539-42.

Sanger F, Nicklen S, Coulson AR. DNA Sequencing with chainterminating inhibitors. Proc Nat Acad Sci USA. 1977; 74(12):5463-68.

Sarver SK, Freshwater DW, Walsh PJ. Phylogenetic relationships of western Atlantic snappers (family Lutjanidae) based on mitochondrial DNA sequences. Copeia. 1996; 1996(3):715-21.

Schwamborn R, Neumann-Leitão S, Silva TA, Silva AP, Ekau W, Saint-Paul U. Distribution and dispersal of decapod crustacean larvae and other zooplankton in the Itamaracá estuarine system, Brazil. Trop Oceanogr. 2001; 29(1):1-18.

Sevilla RG, Diez A, Norén M, Mouchel O, Jérôme M, VerrezBagnis $\mathrm{V}$ et al. Primers and polymerase chain reaction conditions for DNA barcoding teleost fish based on the mitochondrial cytochrome $\mathrm{b}$ and nuclear rhodopsin genes. Mol Ecol Notes. 2007; 7(5):730-34.

Silva AMA, Barbosa JEL, Medeiros PR, Rocha RM, LucenaFilho MA, Silva DF. Zooplankton (Cladocera and Rotifera) variations along a horizontal salinity gradient and during two seasons (dry and rainy) in a tropical inverse estuary (Northeast Brazil). Pan-Am J Aquat. Sci. 2009; 4(2):226-38.

Stamatakis A. RAxML version 8: a tool for phylogenetic analysis and post-analysis of large phylogenies. Bioinformatics. 2014; 30(9):1312-13.

Vergara R. Consideraciones filogeneticas sobre las especies cubanas del genero Lutjanus (Lutjanidae, Perciformes, Teleostei). Inform Cient-Téch. 1980; 113:1-39.

Zink RM, Barrowclough GF. Mitochondrial DNA under siege in avian phylogeography. Mol Ecol. 2008; 17(9):2107-21.

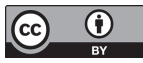

Submitted July 29, 2018 Accepted March 12, 2019 by Claudio Oliveira 